\title{
CAVE PROTECTION AS A KARST CONSERVATION TOOL IN THE ENVIRONMENTALLY SENSITIVE LAGOA SANTA KARST, SOUTHEASTERN BRAZIL
}

\author{
VARSTVO PODZEMNIH JAM KOT ORODJE ZA OHRANITEV \\ KRASA V OKOLJSKO OBČUTLJIVEM KRASU LAGOA SANTA \\ V JUGOVZHODNI BRAZILIJI
}

Augusto S. AULER ${ }^{1}$

\begin{abstract}
UDC UDK: 551.442:502.13(81)

Augusto S. Auler: Cave protection as a Karst conservation tool in the environmentally sensitive Lagoa Santa Karst, Southeastern Brazil

Karst areas in densely populated and industrialized areas in Brazil are under severe environmental pressure due to urbanization, quarrying, groundwater pollution, groundwater overpumping and cave vandalism. Although karst terrains receive no specific protection according to Brazilian environmental law, caves, regardless of rock type, are classified as belonging to the society, and must be studied in detail to have their significance (and related level of protection) determined. Most caves (>90\%) are of either maximum or high significance, which results in protection of not only the cave but also of an associated buffer zone. Given the very conservative definition of cave (a natural void large enough to allow a human being to enter), hundreds of caves will exist in any given outcrop and the amalgamation of buffer zones tends to yield an integrated area that covers most of the karst surface. In the Lagoa Santa Karst, Brazil's most urbanized and industrialized karst area, cave preservation is presently the most effective approach to protecting karst heritage. However, other karst features not connected to existing caves (e.g., covered karst, karst aquifers with no accessible caves, dolines with no associated caves) receive no specific protection. Although this heterogeneous level of protection may yield non-preserved karst areas, the remaining zones tend to be surrounded by protection belts, imposing severe restrictions on urban and mining development and associated sources of potential damage.

Key words: Environmental policy, cave protection, karst preservation, Lagoa Santa Karst.
\end{abstract}

Izvleček

UDK UDK: 551.442:502.13(81)

Augusto S. Auler: Varstvo podzemnih jam kot orodje za ohranitev Krasa v okoljsko občutljivem krasu Lagoa Santa v jugovshodni Braziliji

Kraška območja $\mathrm{v}$ gosto poseljenih in industrijskih predelih Brazilije so zaradi urbanizacije, kamnolomov, onesnaženosti in prekomernega črpanja podzemnih voda ter vandalizma jam pod velikim okoljskim pritiskom. Čeprav kraški tereni v okviru brazilske okoljske zakonodaje niso posebej zaščiteni, so jame del pripadnosti družbi, zato jih je treba podrobno preučevati in določiti njihov pomen ter temu primerno stopnjo zaščite. Večina jam (več kot $90 \%$ ) ima bodisi največjo bodisi visoko mero pomembnosti, kar pomeni zaščito ne samo jam, ampak tudi njihovih tamponskih območij. Ker pa je definicija jame že precej zastarela (vsaka naravna votlina, ki je dovolj velika, da vanjo vstopi človek), to pomeni, da v kateri koli izdanki obstaja na stotine jam, zaradi združevanja tamponskih območij pa pogosto nastajajo povezana območja, ki obsegajo večino kraškega površja. Na kraškem območju Lagoa Santa, najbolj urbanem in industrijskem predelu Brazilije, je ohranitev krasa tako trenutno najbolj učinkovit pristop $\mathrm{k}$ varovanju kraške dediščine. Toda drugi kraški pojavi, ki niso povezani z obstoječimi jamami (npr. pokriti kras, kraški vodonosniki brez dostopnih jam, vrtače brez dostopnih jam idr.), niso deležni nobene posebne zaščite. Čeprav lahko ta raznovrstna stopnja zaščite privede do tega, da bodo določena kraška območja ostala nezaščitena, so preostala območja povečini obdana $\mathrm{Z}$ zaščitnimi pasovi, ki zelo omejujejo urbani razvoj in rudarstvo ter $\mathrm{z}$ njima povezane morebitne vire škode.

Ključne besede: okoljska politika, varstvo jam, ohranitev krasa, kraško območje Lagoa Santa.

\footnotetext{
${ }^{1}$ Instituto do Carste, Rua Aquiles Lobo 297, Belo Horizonte, MG, 30150-160, Brazil, e-mail: aauler@gmail.com Received/Prejeto: 06.03.2016
} 


\section{INTRODUCTION}

Karst terrains are especially sensitive and vulnerable areas in which environmental problems can be magnified (van Beynen \& Townsend 2005; Calò \& Parise 2006). Due to the fertile nature of the soil, many such areas experienced early colonization, resulting in centuries of uncontrolled agricultural and urban activities that caused degradation of the karst landscape and karst waters (Drew \& Hötzl 1999; Chen et al. 2009). In recent times, urban and industrial activities, particularly mining, have encroached in many karst areas, leading to physical alteration of the landscape and the potential total loss of karst features and underground biodiversity (Langer 2001; Parise \& Pascali 2003; Sugai et al. 2015, for a recent review see Gutierrez et al. 2014).

Although each karst landform responds differently to environmental changes, the integrative nature of karst terrains means that the system as a whole can be subject to irreversible impacts (Ravbar \& Šebela 2015). Furthermore, with groundwater flow velocities orders of magnitude higher than in other types of terrains, the transmission of contamination or alterations in water quality can affect vast areas relatively quickly (Ford \& Williams 2007; Vallejos et al. 2015).

The Lagoa Santa Karst in eastern Brazil has been subject to environmental modifications since Portuguese settlement in the late $17^{\text {th }}$ Century. Prior to that, the slash and burn agricultural practices of the native population may have also resulted in modifications in the original vegetation. Caves, in particular, have been targets for exploitation due to saltpeter mining, commercial and scientific paleontological excavations and vandalism.

During the late $20^{\text {th }}$ and throughout the $21^{\text {st }}$ Century, increased economic development in Brazil led to marked urbanization of the Lagoa Santa Karst, and grad- ual integration with the nearby metropolis of Belo Horizonte. A significant number of lime and cement plants were installed and several new urban developments were approved, which led to an increase in both economic activity and threats to karst environments. However, in recent years, efforts have been undertaken towards the establishment of conservation units, leading to selective preservation of areas that retain representative karst landscapes.

A recent (2008) change in cave related environmental laws resulted in a strong emphasis on cave preservation without mentioning other karst landforms (Auler \& Piló 2015a). However, the strict nature of the law, which requires a much larger protection buffer zone for each underground void of length beyond a few meters, may potentially encompass much of the surrounding karst landscape. Furthermore, in the scenario of possible cave destruction, two other cave equivalents must be protected. This situation has created the potential for the permanent preservation of a considerable number of caves, making mining expansion difficult. Although this conservative law represents a major economic setback for mining operations in Brazil, it creates interesting, although challenging, opportunities for preserving environmentally significant areas of karst.

The current work presents a case study of the heavily populated and industrialized Lagoa Santa Karst as an example of the present environmental situation of karst areas in Brazil. Caves are currently the only landforms that legally provide protection for karst areas. Although these are an essential part of the karst environment, caves tend to be overemphasized and treated as features not integrated with the surrounding karst system.

\section{STUDY AREA}

The Lagoa Santa Karst is located in the south central state of Minas Gerais, approximately $30 \mathrm{~km}$ north of the metropolis of Belo Horizonte, the state capital. The area derives its name from the town of Lagoa Santa (Sacred Lake), which was an important urban center in the area during the $18^{\text {th }}$ and $19^{\text {th }}$ centuries, prior to the inauguration of Belo Horizonte in 1897.

The area displays well-developed karst topography developed on Precambrian carbonate rocks of the Bambuí Group. These carbonate rocks belong to the lowermost Sete Lagoas Formation, which is divided into the basal Pedro Leopoldo Member and the upper Lagoa Santa Member (Tuller et al. 1992). The lower Pedro Leopoldo Member is characterized by impure limestone with intercalations of pelites and siltstone, while the upper Lagoa Santa Member is of purer calcarenites and calcisiltites. Chemical analyses reported by Piló (1998) show a marked increase in silica and a decrease in calcium carbonate in the lower Pedro Leopoldo Member. The carbonates have thin, nearly horizontal laminations. Dips in the area normally do not exceed $5^{\circ}$. 


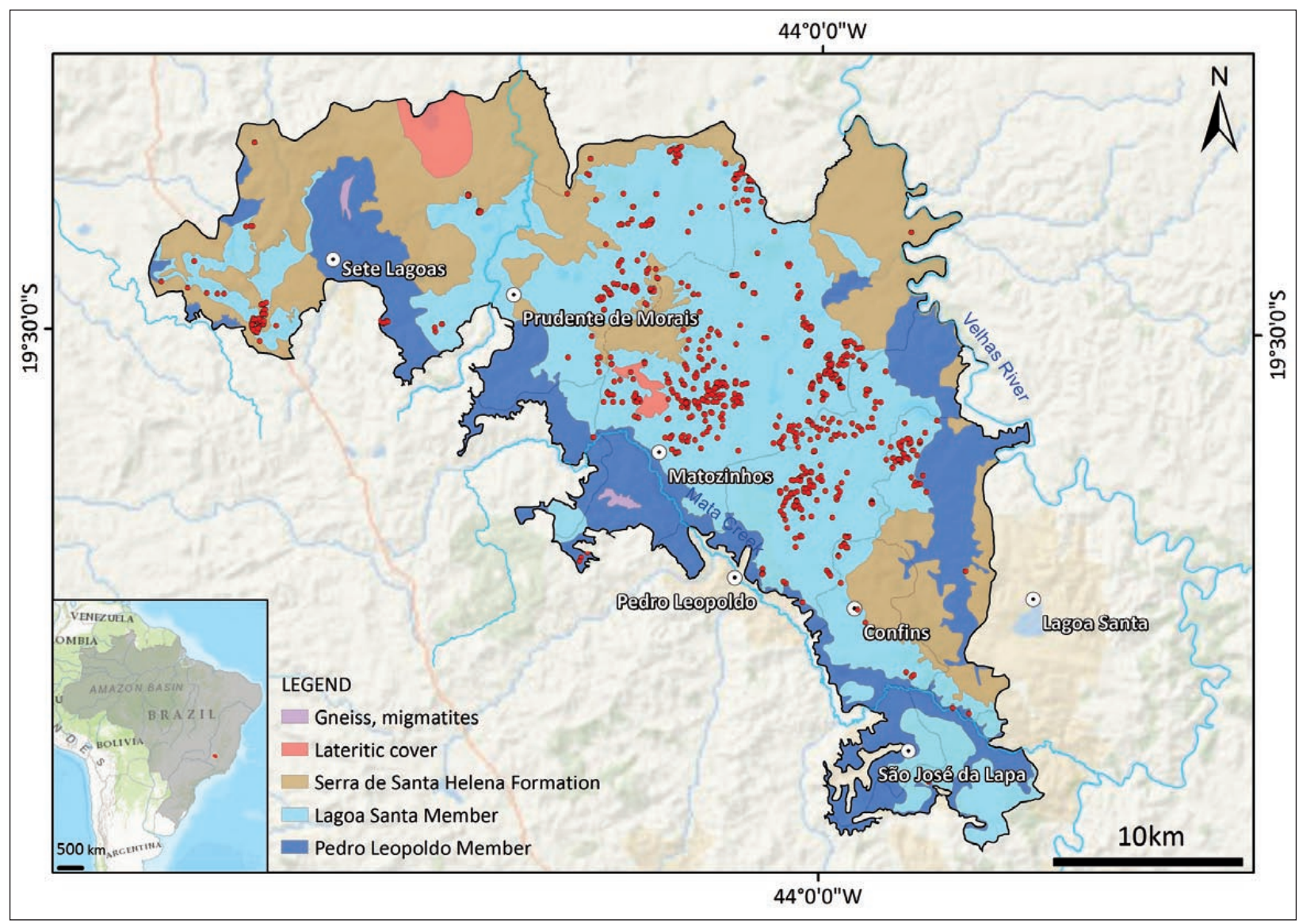

Fig. 1: Boundaries of the Lagoa Santa Karst, showing the geology and officially recorded caves (red dots) according to the Brazilian government (CECAV 2016) database. Due to clustering of caves, individual red dots may represent several caves. Map source: ArcGIS basemap.

Metamorphic siltstones of the upper Serra de Santa Helena Formation outcrop in a few areas and form most of the northern limit of the karst. To the west and south, boundaries are marked by Archean gneisses and migmatites, limited roughly by Mata Creek. To the east, the Velhas River (the major base level river of the area) is commonly considered the karst eastern limit (Fig. 1). The total karst area comprises approximately $816 \mathrm{~km}^{2}$, much of it dominated by a thick (up to $60 \mathrm{~m}$ ) soil cover, including lateritic deposits. Limestone outcrops mostly in vertical cliffs and in a few exhumed karst massifs. A recent review of the karst landforms in the Lagoa Santa area is presented by Auler and Piló (2015b). Climate is highly seasonal, with a wet season between November and March (Austral summer) and dry season mostly between June and September. Total annual rainfall averages $1,300 \mathrm{~mm}$.

The area harbors a large number of caves. In February 2016 the official national cave database listed 931 caves (CECAV 2016). However, ongoing environmental assessment studies have recently added several new caves, increasing the total to over 2,000. The majority of the caves are small, shallow occurrences, densely packed in the studied outcrops. Most represent segments of systems that were once more extensive, mostly of paragenetic origin, divided by cliff and massif fragmentation (Auler 1999). Tab. 1 lists the main characteristics of Lagoa Santa Karst caves.

The Lagoa Santa Karst caves became internationally known due to the paleontological and archaeological findings of Danish naturalist Peter Wilhelm Lund (Lund $1840,1845)$. These findings form the basis of Brazilian Pleistocene paleontology (Paula Couto 1953). Lund's work found worldwide appeal due to the number of new fossil findings and their association with human remains (Neves \& Piló 2003; Neves \& Hubbe 2005; Neves et al. 2007; Piló et al. 2005). The area became the focus of scientific pilgrimage for many scientists during the $19^{\text {th }}$ Century including Hermann Burmeister, Emmanuel Liais, Richard Burton, Virgil von Helmreichen, and Marianne North, among several others. Further scientific excavations in the caves were performed during the $20^{\text {th }}$ and $21^{\text {st }}$ centuries and many relevant findings are associ- 
Tab. 1: Main characteristics of Lagoa Santa Karst caves.

\begin{tabular}{l|l|l|l|l}
\hline Speleogenesis & Location & Pattern & Frequency & Source \\
\hline Paragenesis & $\begin{array}{l}\text { Mostly in relict towers, but also at } \\
\text { doline bottoms }\end{array}$ & $\begin{array}{l}\text { Meandering anastomotic canyon- } \\
\text { shaped passages }\end{array}$ & $\begin{array}{l}\text { Dominant } \\
\text { Fuler (1999), } \\
\text { Auler et al. 2009 }\end{array}$ \\
\hline Floodwater & $\begin{array}{l}\text { Baseof dolines filled by (past or } \\
\text { present) permanent or ephemeral lakes }\end{array}$ & $\begin{array}{l}\text { Network maza, narrow and high } \\
\text { linear passages }\end{array}$ & Common & Auler (1995) \\
\hline Talus & lrregular fissure-like passages & Common & \\
\hline
\end{tabular}

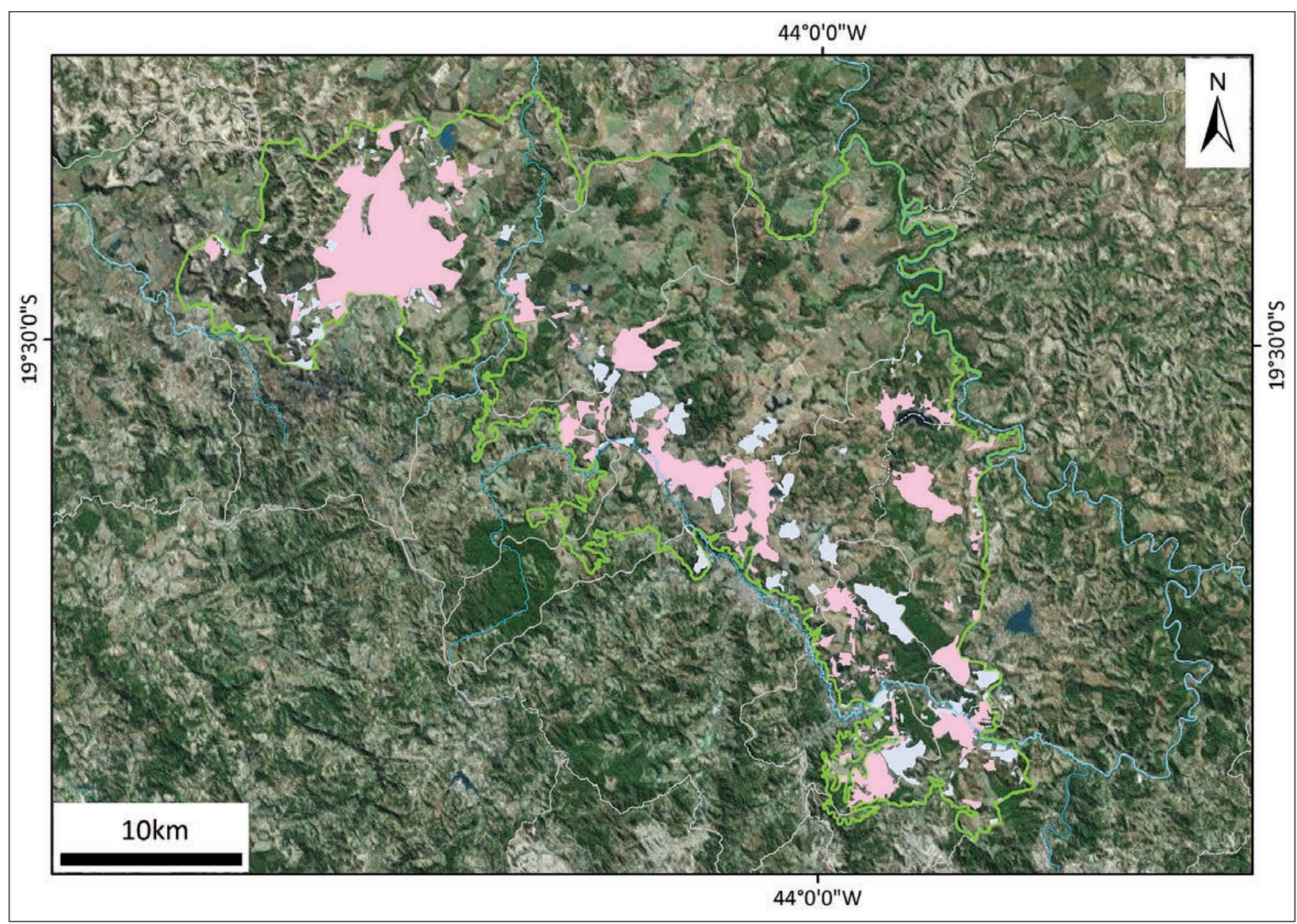

Fig. 2: Urban areas (pink) and industrial zones (light blue) over the Lagoa Santa Karst (boundary in green line). Map source: ArcGIS basemap.

ated with the caves (Neves \& Hubbe 2005; Hubbe et al. 2011; Araújo et al. 2012; Strauss et al. 2015).

Rapid urban encroachment occurred from the mid1950s with the growth of Belo Horizonte and the construction of an international airport over the karst area. Rapid industrialization and growth of the towns of Lagoa Santa, Matozinhos, Pedro Leopoldo, Prudente de Morais and Sete Lagoas (to name only the most important ones) have increased the population living within (or bordering) the karst area to over 500,000 people. There are approximately 15 cement and lime plants, and new urban and industrial development projects are being planned over the area. Despite the recognition of the importance of the Lagoa Santa Karst, it is only recently that conservation units were effectively created. The most important of those is the Sumidouro State Park, encompassing approximately $20 \mathrm{~km}^{2}$ of prime karst terrains. Presently, official conservation units total approximately $23 \mathrm{~km}^{2}$. Private preservation sites (mostly owned by mining companies but also belonging to local farmers) would add an additional $10 \mathrm{~km}^{2}$ to the total area of currently preserved karst. Figure 2 shows the major industrial sites and urban centers over the karst that covers approximately $137 \mathrm{~km}^{2}$ (16.8\% of the total karst area). 


\section{METHODS}

Due to its proximity to the state capital and growing economic importance, the Lagoa Santa Karst has been subject to several environmental studies and extensive mapping. For this study the relatively vast body of images was used, including aerial photographs, detailed (1: 10 000) orthogonal aerial photographs and satellite images. Map layout was based on ArcGIS base map database. The advance of industries and urban centers has been mapped by comparing earlier and latter images, in which bases for each impact source (mining, industry, urban centers, etc.) were manually vectorized. ArcGIS tools were applied to select and calculate the areas, allowing the quantification of the environmental impact as well as the definition of trends in land use.
Cave databases in Brazil are spread among a number of sources, including the Brazilian Speleological Society and local club sources. However, the most complete source by far is held by the federal government. Any new cave studied during environmental assessment studies has to be registered in the CANIE (National Register for Speleological Information), the national cave database hosted by CECAV (National Center for Study and Conservation of Caves) under the Ministry of the Environment. This database (CECAV 2016) was the main source of information regarding registered caves in the study area. Further information was gathered from various sources, including archives of environmental companies and private information.

\section{ENVIRONMENTAL IMPACTS}

Karst terrains in Brazil comprise, in general, fragile and fertile areas where agriculture and colonization have been favored since early human settlement. Doline bottoms, karst springs and caves have been used for millennia. The Lagoa Santa Karst is surrounded by soil-poor igneous and metapelite rocks, making the limestone a naturally more favorable area for settlement. The various activities that have affected the Lagoa Santa Karst have dramatically altered the natural landscape since the arrival of European settlers in the late 1600s.

\section{DEFORESTATION}

The first Portuguese settlers in Brazil described the slash and burn technique used by Indians for clearing the land for agriculture. In fact, the first scientists to visit the area in the $19^{\text {th }}$ Century doubted whether the savannah veg- etation, typical of the area, was the original primary vegetation type or a secondary growth following the burning cycles (Lund 1837). The savannah vegetation, locally known as "Cerrado" is now accepted as one of the typical biomes of Brazil. In the area within the Cerrado, however, dry forest occurs associated with limestone outcrops and areas with shallow soil, such as steep slopes. These dry forests are confined to limestone surfaces and include endemic species not found elsewhere.

Large farms were established in the area starting in the late $18^{\text {th }}$ Century. The proximity to the mining districts to the south and its growing population resulted in the establishment of cattle farms for dairy and meat. This led to the clearance of much of the vegetation, mostly during the early $20^{\text {th }}$ Century. Currently, the original Cerrado vegetation has been almost entirely replaced

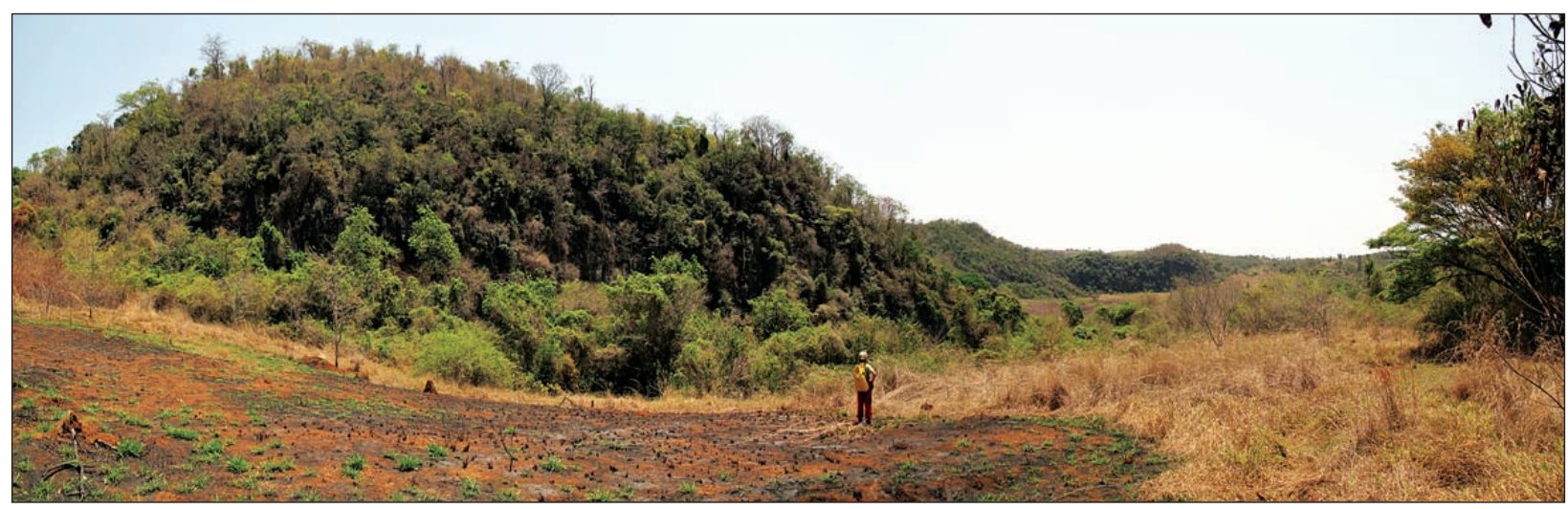

Fig. 3: View of limestone outcrop with preserved dry forest vegetation with surroundings cleared for agriculture (Photo: L. Alt). 


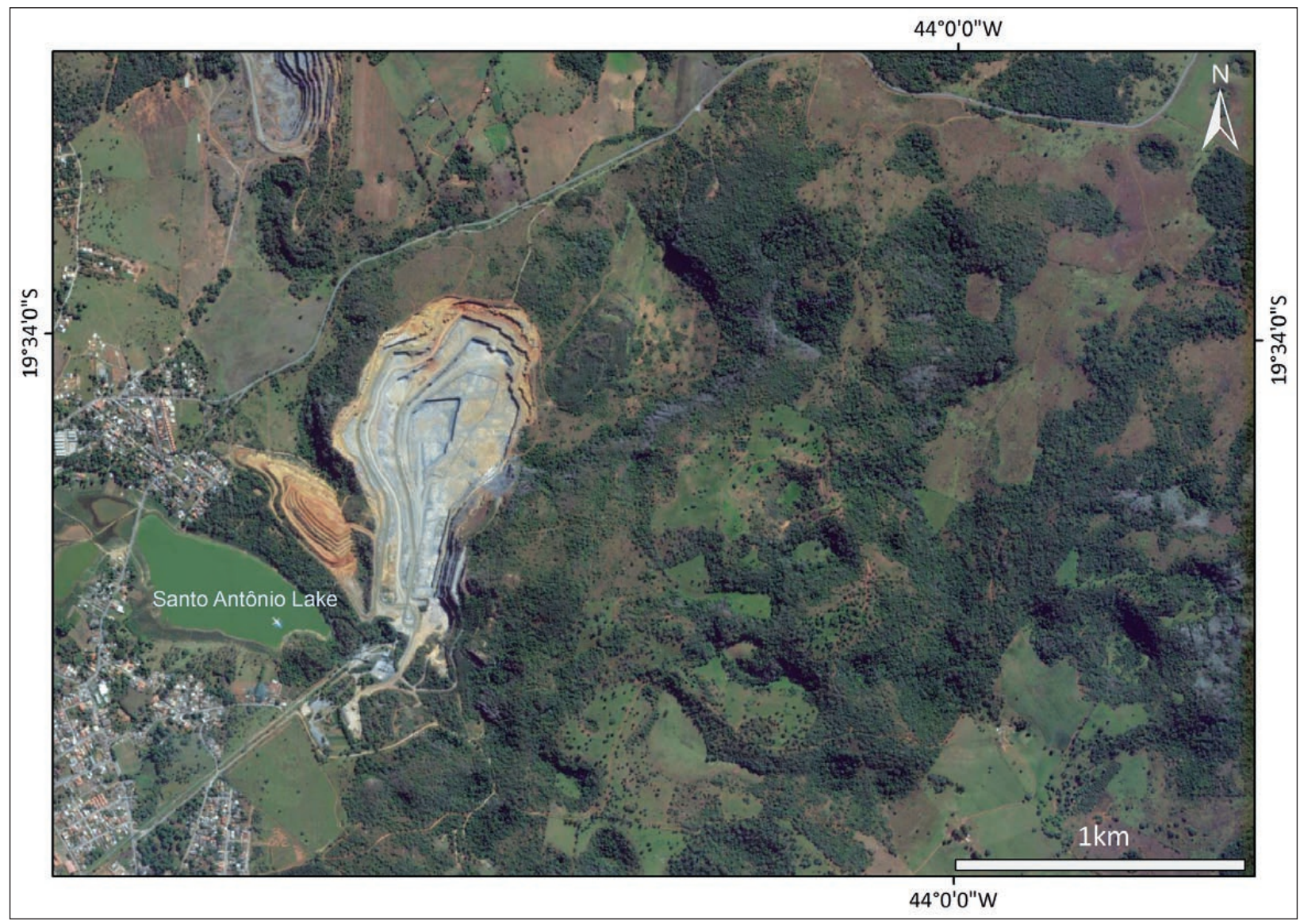

Fig. 4: Aerial view of the southern sector of the Lagoa Santa Karst showing an urban center (left), quarries (center left and upper left) and forested/pasture land. The original vegetation has been preserved in outcrop areas, steep slopes or doline bottoms. Map source: ArcGIS basemap.

by grasslands for cattle/horse ranching or agriculture. However, the original vegetation has been preserved in outcrop areas not suitable for ranching (Fig. 3 ) or in steep doline bottoms or slopes (Fig. 4), although late $20^{\text {th }}$ Century mining development has removed some of these isolated patches of forest. Groundwater pollution by pesticides and cattle manure is an ongoing threat to water resources.

An analysis of past and present vegetation shows that nearly $16 \%$ of the area has been cleared due to urban growth, cattle ranching or various agricultural practices; even officially preserved areas no longer retain the original vegetation. Exceptions are private reserves belonging to mining companies and to a few ecologically minded farmers.

The removal of vegetation cover in karst leads to soil erosion, especially in steep slopes (Harding \& Ford 1993). In the study area, this results in the creation of gullies and infilling of dolines and caves, a process that has been demonstrated to be driven by past drier climates (Auler et al. 2009) but that has now been reactivated due to anthropogenic modifications of land use.

\section{URBANIZATION}

The early settlements in the area date from the 1690s, when the first Portuguese explorers reached the area in search of mineral wealth. Small villages were established and a route between the colony capital in the coast and the northern states through the São Francisco river valley was created, cutting across the area (Lima Jr. 1965). Villages such as Lagoa Santa were established in this period. The area remained relatively rural until the end of the $19^{\text {th }}$ Century when the state capital was transferred to the newly built city of Belo Horizonte. The rapid development of Belo Horizonte led to increasing urban growth in towns inside and surrounding the karst, such as Pedro Leopoldo, Lagoa Santa, Matozinhos, Prudente de Morais, Funilândia and Sete Lagoas. Tab. 2 shows the rapid population expansion in the area within or immediately bordering the Lagoa Santa Karst. 
Tab. 2: Population growth in urban areas associated with the Lagoa Santa Karst.

\begin{tabular}{l|l|l}
\hline Year & $\begin{array}{l}\text { Population within } \\
\text { the karst }\end{array}$ & $\begin{array}{l}\text { Population in the vicinity of } \\
\text { the karst }\end{array}$ \\
\hline 1970 & 54,155 & 75,981 \\
\hline 1980 & 84,802 & 115,746 \\
\hline 1991 & 131,380 & 175,689 \\
\hline 2000 & 183,442 & 235,991 \\
\hline 2010 & 222,444 & 285,787 \\
\hline
\end{tabular}

The construction of the Belo Horizonte International Airport in 1984 and its expansion since 2012 has shifted much of the capital urban and industrial development to the area within or surrounding the Lagoa Santa Karst, creating new industrial districts and a growing population in newly planned low-rise condominiums. To service the increasing population, new roads, electricity power lines and sewage systems were built, especially in the southwestern limit of the area close to the major cities of Pedro Leopoldo and Matozinhos. Uncontrolled urbanization still occurs in many areas of the karst and the flexibility of the urban regulatory system coupled with the irregular occupation of land plots provides further threats to karst ecosystems. Occupation occurs very close to caves, in the catchment zone of dolines and closely associated with springs and swallets; additionally, landfills are improperly located in recharge zones leading to caves (Fig. 5).

Uncontrolled urban development over the karst led to groundwater pollution due to improper sewage systems and alteration in the flow in the recharge zones. Furthermore, groundwater pumping for both indus- trial and home use has increased dramatically in recent years. In the Sete Lagoas urban area, groundwater levels have dropped $40 \mathrm{~m}$ since the 1940s, resulting in frequent sinkhole collapse events (Galvão et al. 2015).

\section{MINING}

The earliest record of mining activities in the Lagoa Santa Karst comes from saltpeter mining in the late $18^{\text {th }}$ Century, peaking in the early 1800 s (Gomes \& Piló 1991). At the time, cave saltpeter was an essential ingredient for gunpowder and hundreds of caves had their soil removed for nitrate extraction. The impact of saltpeter mining in the karst, although severe, is mostly restricted to caves.

Beginning in the mid-1950s, widespread mining for cement and lime production occurred in the southwestern limit of the area, close to urban centers. Today there are approximately 15 quarries and associated plants. Although quarries occupy just a small portion of the karst, permanent damage to karst features and caves occurred in the past, before a more comprehensive environmental policy raised the standards for mine licensing. Quarries and plants tend to concentrate near urban centers and major roads, especially in the southwestern limit of the area (Fig. 6). In addition to cave quarrying, air particulates dispersed primarily from lime plants have covered the walls and floors of many caves, a type of environmental impact that is difficult to restore and with unknown effects on cave fauna.

\section{CAVE VANDALISM}

In many caves, Paleoindian use, saltpeter mining and paleontological excavation have resulted in considerable

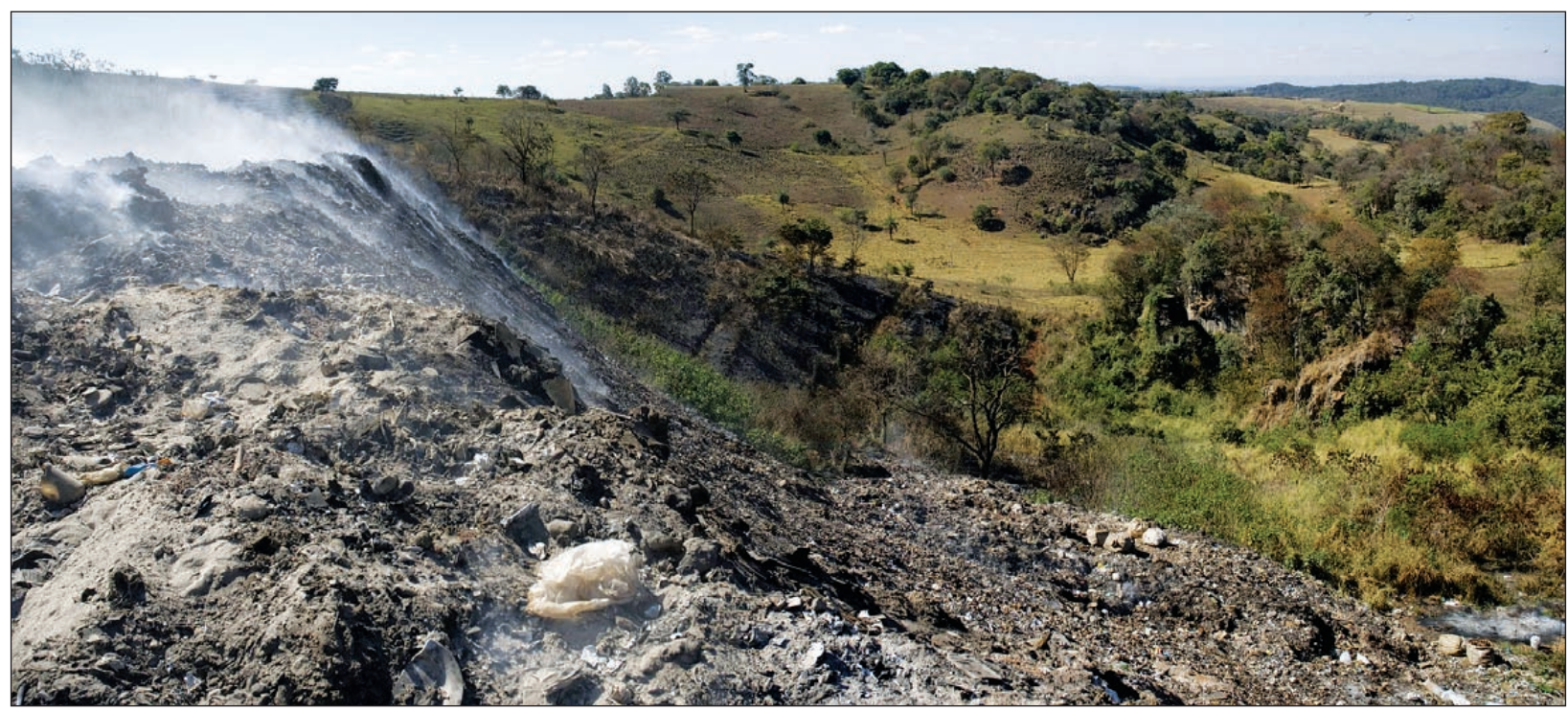

Fig. 5: View of the Matozinhos landfill, located in a recharge zone leading to dolines and caves (Photo: L. Alt). 


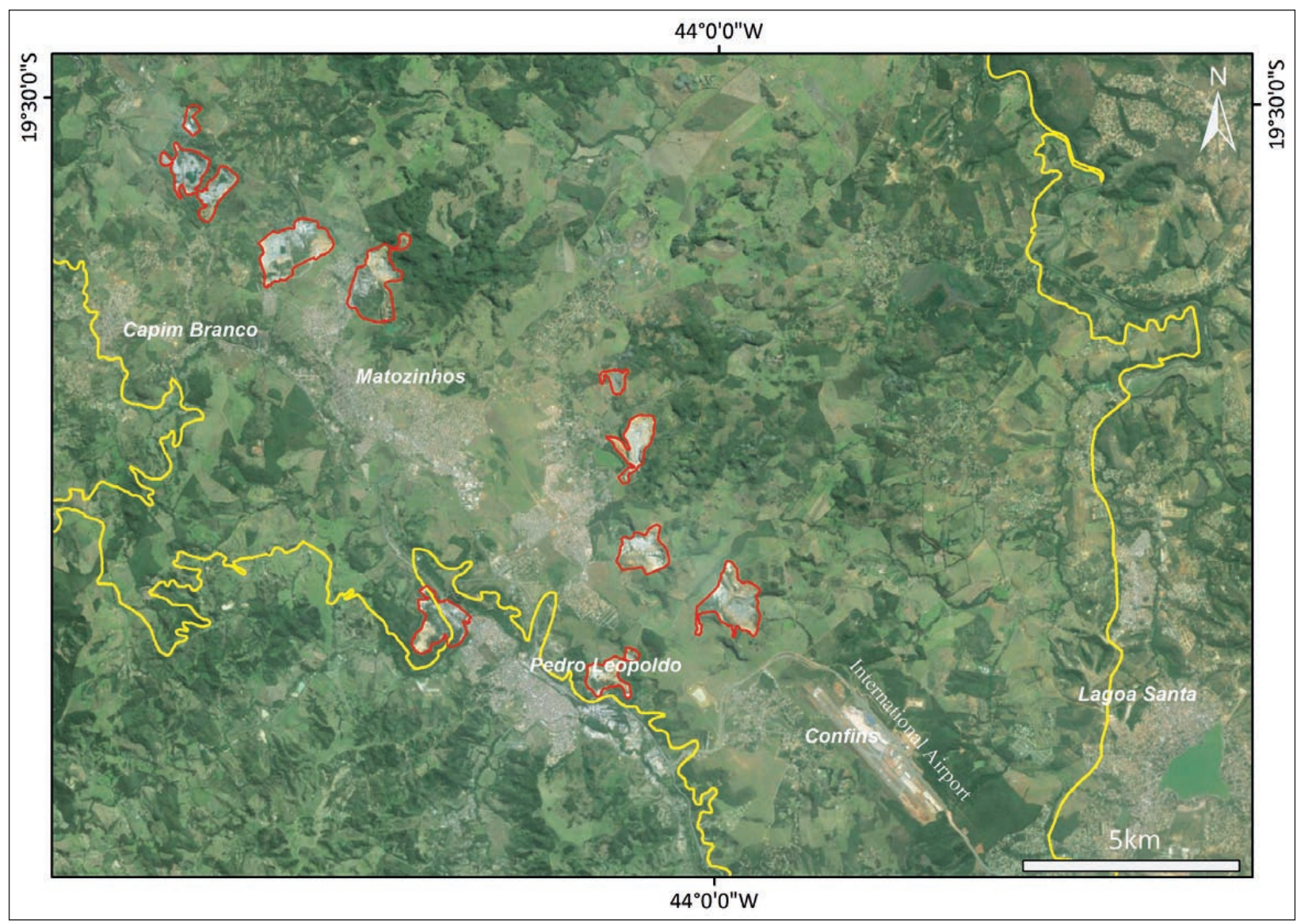

Fig. 6: Aerial image of the southern portion of the Lagoa Santa Karst, showing major urban centers of Lagoa Santa, Pedro Leopoldo and Matozinhos, the international airport and some of the existing lime and cement quarries and plants (in red). Source: ArcGIS basemap.

modification of the original cave morphology, especially in relation to the floor configuration.

Two caves have been adapted to mass tourism (Lapinha and Rei do Mato caves). In both, considerable modification of some passages and the placement of iron stairs and walkways have resulted in permanent changes to some sections of the caves. Due to urbanization, many caves are very close to urban centers, resulting in occasional uncontrolled visitation. Many caves have been heavily vandalized, especially by graffiti and speleothem breakage.

\section{CAVE PRESERVATION AS A KARST PROTECTION TOOL}

Prior to 1988, caves and karst in Brazil had limited protection. In 1988, during the promulgation of the new constitution, caves were included in the same category as the ocean, rivers and underground resources, as belonging to all citizens (Brasil 1988). Caves, thus, became naturally protected, as their use (or destruction) would depend on approval by the federal government. In 1990 , Directive 887 by IBAMA (The Brazilian Institute of Environment and Renewable Natural Resources), stated that caves should be included in environmental studies and could be used only for technical and scientific purposes, including tourism and educational and cultural activities (IBAMA 1990). This same Directive also added a protection buffer zone for each cave. The protection buffer is a $250 \mathrm{~m}$ perimeter drawn perpendicular from the cave walls. The dimension and definition of the buffer zone were not based on any scientific study and result in a smoothed outline of the plan map of the cave (Fig. 7). The $250 \mathrm{~m}$ perimeter yields a considerably larger area of approximately $0.2 \mathrm{~km}^{2}$ for each cave. Any karst fea- 
ture within this perimeter is automatically preserved. However, this buffer zone represents just a preliminary protection zone. Further studies, if approved by the environmental agency, can modify (increase or decrease) the protection zone. The rationale behind further studies to redefine the protection buffer is to protect not only the integrity of the cave (against blasting from nearby quarries, groundwater pollution, etc.) but also to preserve the dynamics of the cave in terms of its ecosystem (no impact on cave fauna) and sediment and water input. For example, a cave that contains an underground stream would have its preliminary buffer zone dramatically expanded to include the entire catchment area of the stream.

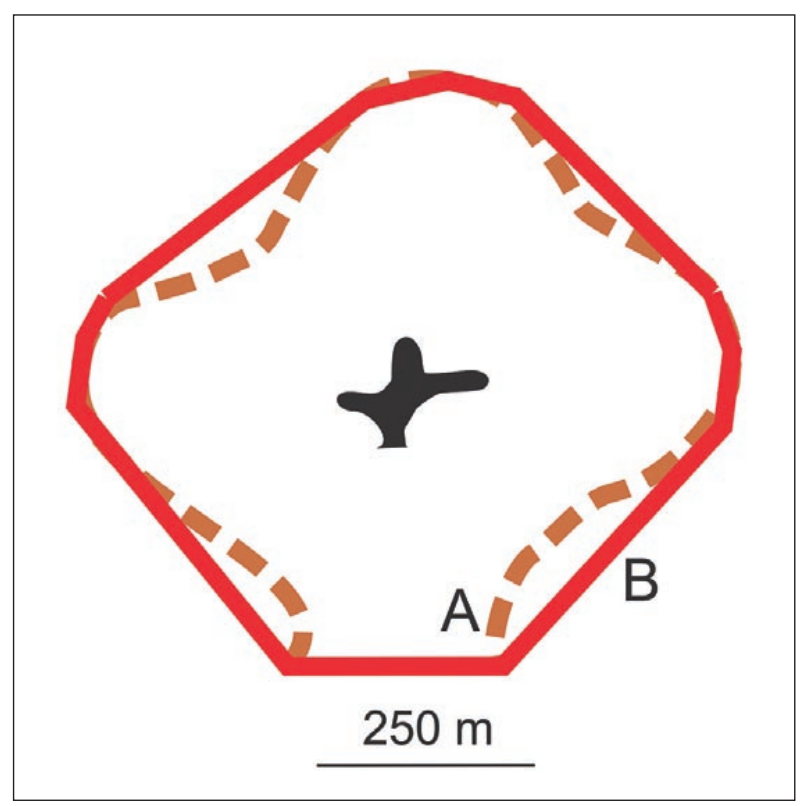

Fig. 7: The preliminary standard buffer zone is represented by a $250 \mathrm{~m}$ projection perpendicular from the walls of the cave (plan view in black), resulting in an area with a minimum of 19.6 hectares. The brown dashed line represents the original projection. Because the elimination of the concave sections is required, the red line represents the final protection buffer.

This very strict legislation implied the permanent protection of all caves, regardless of significance, making it difficult for new developments (mostly mining operations and hydroelectric power plants) to install or expand their activities. A further development occurred in 2004, when Normative Resolution 347 from CONAMA (National Environmental Commission; CONAMA 2004) recognized the need to determine the significance of caves. This initiative was expanded in 2008, when Federal Decree 6640 established four levels of cave significance: Maximum, High, Medium and Low (Brasil 2008), further detailed by Normative Instruction 2 by the MMA (Ministry of Environment) (MMA 2009).
Tab. 3: Speleological criteria related to maximum or high significance caves (MMA 2009). If a single criterion is met, the cave qualifies to the correspondent significance level.

\begin{tabular}{|c|}
\hline Maximum significance \\
\hline I- Unique or rare genesis \\
\hline II - Unique morphology \\
\hline III - Notable dimensions in length, area or volume \\
\hline IV - Unique speleothems \\
\hline V-Geographical isolation \\
\hline $\mathrm{VI}$ - Essential shelter for threatened species \\
\hline VII - Essential habitat for endemic or relict troglobites \\
\hline VIII - Habitat for a rare troglobite \\
\hline IX - Unique ecological interactions \\
\hline $\mathrm{X}$ - Significant paleoenvironmental importance \\
\hline $\mathrm{XI}$ - Significant historic, cultural and religious value \\
\hline High significance \\
\hline I-Type locality \\
\hline $\begin{array}{l}\text { II - Established populations of species with important } \\
\text { ecological role }\end{array}$ \\
\hline III - New taxons \\
\hline IV - High species richness \\
\hline V-High relative abundance of species \\
\hline $\mathrm{VI}$ - Peculiar fauna composition \\
\hline VII - Troglobites that are not rare, endemic or relict \\
\hline VIII - Troglomorphic species \\
\hline IX - Obligatory trogloxenes \\
\hline X-Population of exceptional size \\
\hline $\mathrm{XI}$ - Rare species \\
\hline $\begin{array}{l}\text { XII - High length when compared to other caves at regional } \\
\text { scale }\end{array}$ \\
\hline $\begin{array}{l}\text { XIII - High area when compared to other caves at regional } \\
\text { scale }\end{array}$ \\
\hline $\begin{array}{l}\text { XIV - High volume when compared to other caves at regional } \\
\text { scale }\end{array}$ \\
\hline XV - Significant presence of rare speleogenetic features \\
\hline $\begin{array}{l}\mathrm{XVI} \text { - Perene lake or underground drainage, with marked } \\
\text { influence over any of the criteria in this table }\end{array}$ \\
\hline $\begin{array}{l}\text { XVII - Diversity of chemical deposition with many types of } \\
\text { speleothem and varied processes of deposition }\end{array}$ \\
\hline XVIII - Notable configuration of speleothems \\
\hline XIX - High influence of the cave over the karst system \\
\hline $\mathrm{XX}$ - Interrelation of the cave with a maximum relevance cave \\
\hline $\begin{array}{l}\mathrm{XXI} \text { - Aesthetic and scenic values of national and international } \\
\text { significance }\end{array}$ \\
\hline $\begin{array}{l}\text { XXII - Systematic public visitation with a regional or national } \\
\text { scope }\end{array}$ \\
\hline
\end{tabular}

Based on these documents, caves of maximum significance should be protected together with a buffer zone. Caves of high significance can be impacted, but an environmental compensation of two other caves of equally high significance with respective protection buffer in the same area or bedrock must be permanently protected. Caves of medium significance can also be impacted and require environmental compensation, though not necessarily cave preservation. Caves of low significance can be 
Tab. 3 lists the criteria required for a cave to be assigned maximum or high significance. Meeting any one of these criteria is enough for a cave to qualify as of maximum or high significance. Due to the strict nature of this classification scheme, approximately $15 \%$ of all caves reach the status of maximum significance and $80 \%$ are of high significance; less than $5 \%$ of all studied caves are of medium significance. According to the present criteria, there are no caves of low significance because at least one of the criteria for maximum, high or medium significance is inevitably met.

The official Brazilian definition of a cave, a natural void large enough to allow the entry of a human being (Brasil 2008), also poses additional constraints. Taken verbatim, this definition classifies caves as voids larger than $1.7 \mathrm{~m}$ (the estimated average height of a human being), resulting in hundreds or even thousands of "caves" in most limestone outcrops. To confirm the status of these small voids as caves, further analysis to determine levels of luminosity and stability of temperature and hu- midity in the distal portions of these caves is required. With the present scenario dictating that nearly all caves are either of maximum or, more commonly, of high significance, mining operations face a challenging scenario. The expansion of quarries and the development of new projects will inevitably involve many caves - some permanently protected, others requiring the preservation of two caves of high significance - to be mined (Auler \& Piló 2015a).

A further development was provided more recently by Directive 30 by ICMBIO (Chico Mendes Institute of Biodiversity) (ICMBIO 2012). If there are no caves in the same setting available for compensation (normally because they do not belong to the developer), caves elsewhere can be proposed, together with other compensation measures, such as purchasing land for National Parks or for other conservation areas containing caves. The cost of such environmental compensations varies but more than US $\$ 500,000$ can be spent for each cave that will be permanently impacted.

\section{DISCUSSION}

The Lagoa Santa Karst had approximately 500 officially registered caves prior to 2008 , mostly explored by amateur caving clubs. Small caves were often not taken into account. However, during speleological environmental assessment studies, the official definition of cave must be applied and thus several smaller caves are recognized, resulting in a dramatic increase in the number of known caves. At present, approximately $45 \%$ of the total area of limestone outcrops has not yet been subject to detailed speleological prospecting (Fig. 8). Because average distance between caves is usually much less than the width of the buffer zone, superposition of buffer zones will invariably result in the protection of the entire outcrop (Fig. 9).

Areas of covered karst, where the absence of limestone outcrops limits the occurrence of caves, receive no legal protection. Although removal of the soil cover may represent a considerable cost for mining operations, some companies are choosing to operate in covered karst areas due to the lack of cave-related restrictions. However, in many situations, the distance between outcrops is shorter than the extension of cave buffer zones located close to the outer limit of neighboring outcrops (Fig. 9); this will also lend protection to covered karst areas.

A number of preservation areas were created starting in the late 1980s, but they have only recently been effectively established (Fig. 10). Although these areas represent a small fraction of the entire karst area (less than $3 \%$ ), they often encompass some of the most significant caves. However, due to the lack of governmental funds to promote adequate law enforcement, the status of "protected area" does not effectively prevent environmental damage. Cave vandalism, groundwater pollution and contamination by air particulates are among the most serious threats that occur in protected areas. In addition to the official conservation areas, mining companies and conscientious landowners protect (in a more effective way) significant portions of the karst. Some of these areas have become "islands" of preservation within environmentally degraded surroundings and have thus become natural targets for future official conservation areas.

Although a trend towards establishing additional conservation areas can be observed, conservation areas still cover only a minor portion of the Lagoa Santa Karst. Furthermore, the coverage of protection is heterogeneous, being concentrated in areas with limited population growth. For example, the southwestern limit of the study area, where most of the major urban areas and mining companies are concentrated (Fig. 6), has experienced major urban growth in recent years with limited compensation in terms of protection areas, despite being a recharge area. In such a situation, the protection pro- 


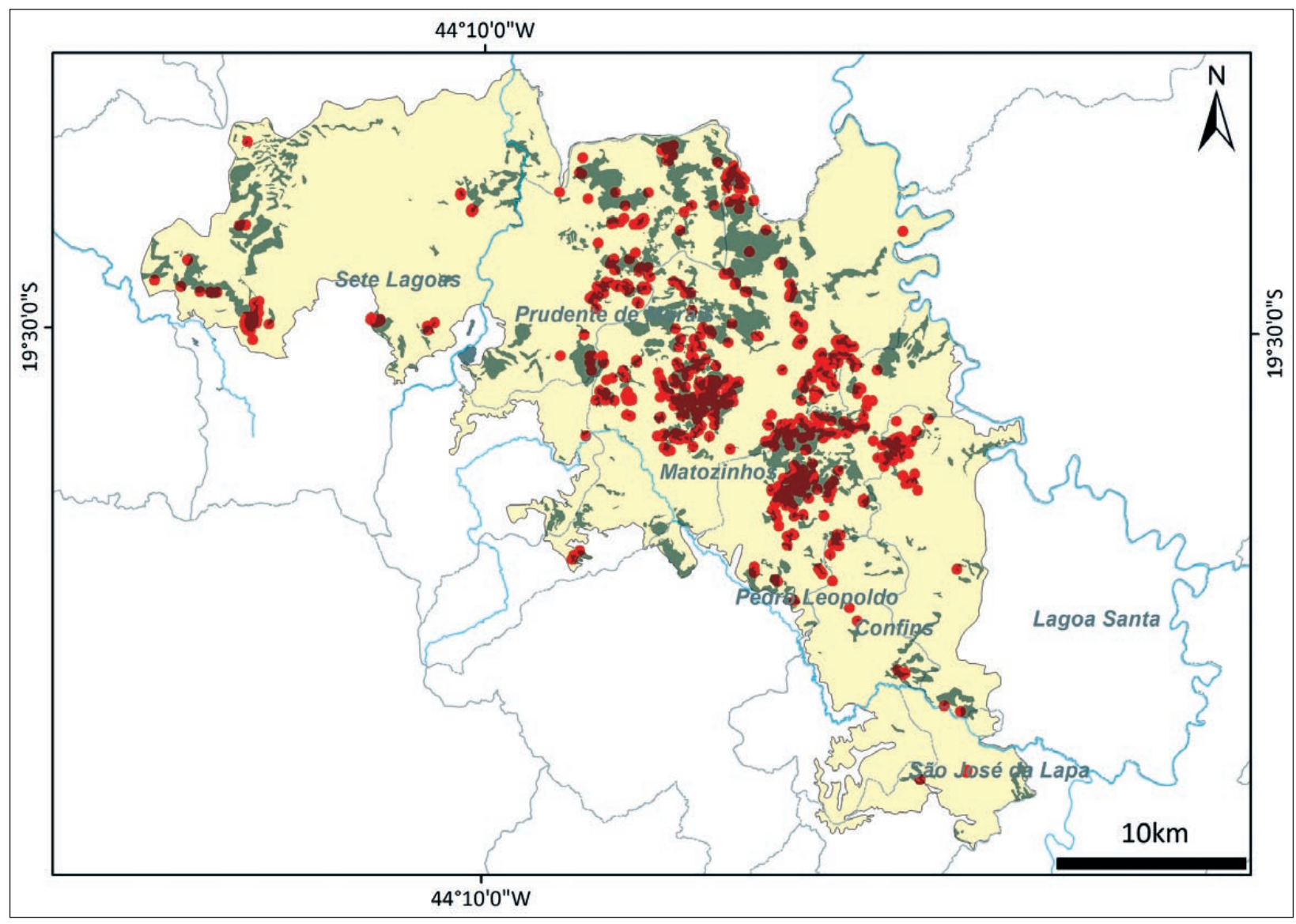

Fig. 8: Areas of limestone outcrop (grey) showing registered caves with protection buffer. Outcrops without caves have not yet been subject to speleological assessment. Source: ArcGIS basemap.

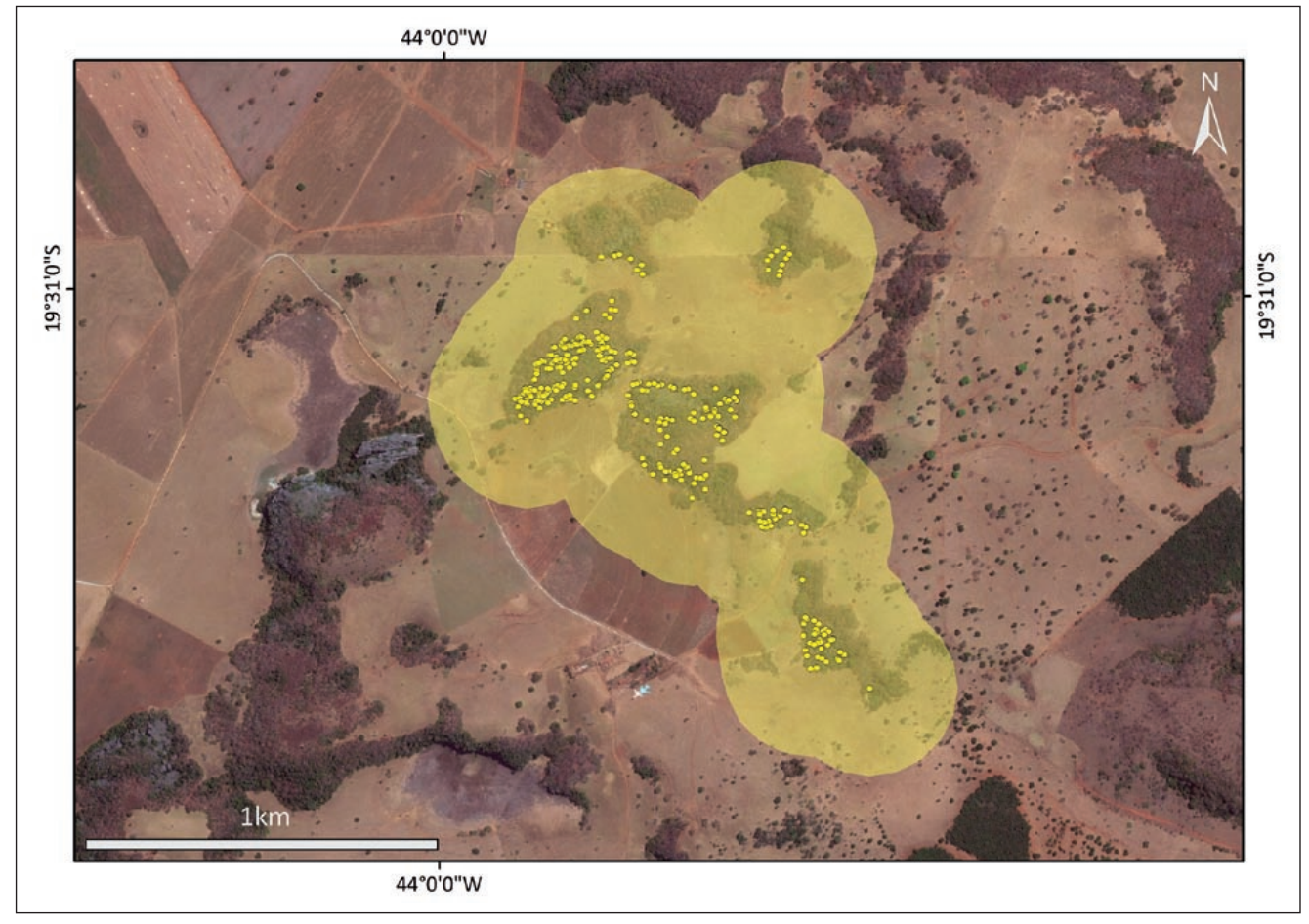

Fig. 9: An example of limestone outcrops containing 412 caves (yellow dots). The superposition of buffer zones (light yellow) leads to the preservation of not only the outcrops but also areas of covered karst between outcrops. Source: ArcGIS basemap. 


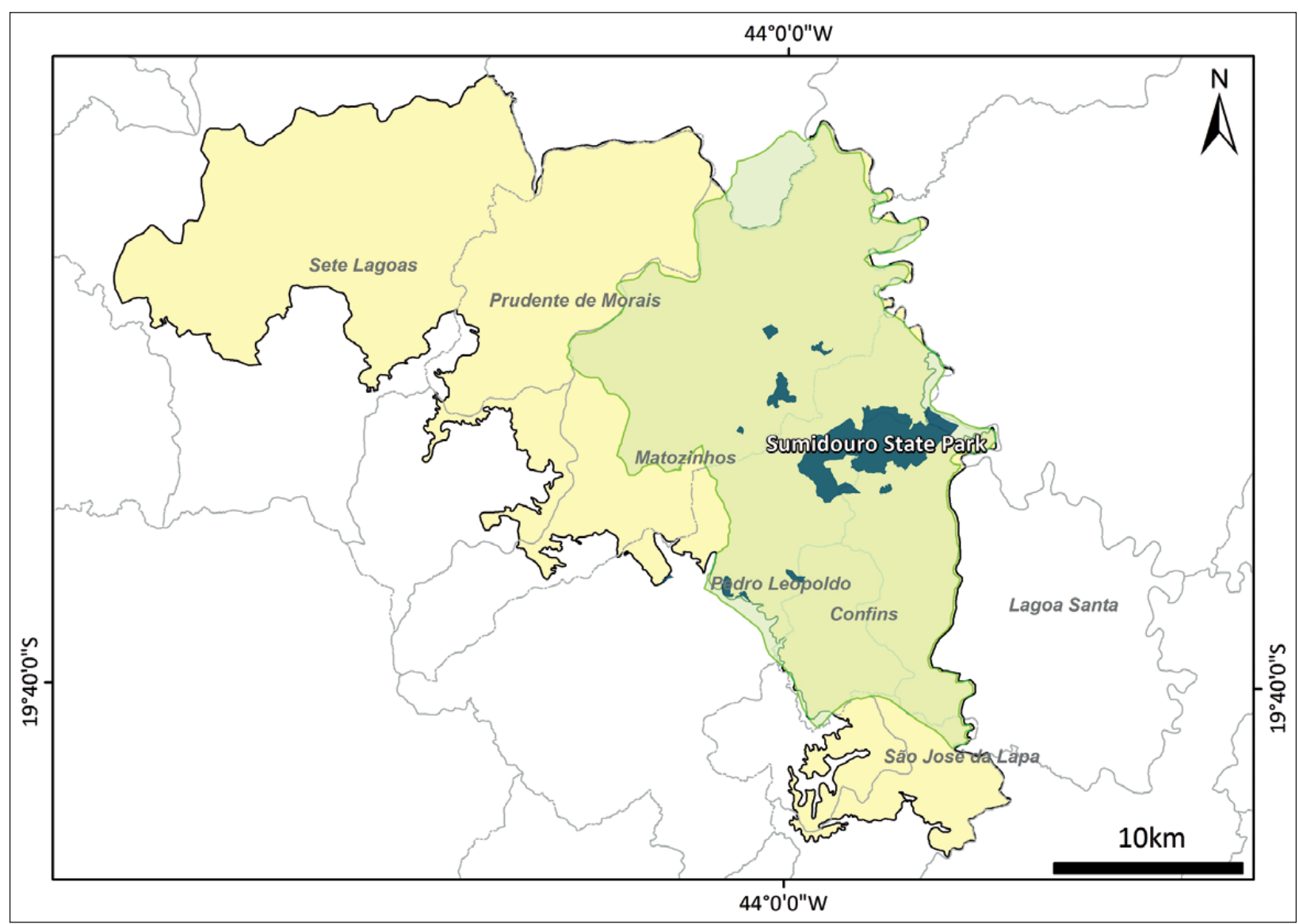

Fig. 10: Current protected areas in the Lagoa Santa Karst (dark green). The area in light green has an "APA" (Environmental Protection Area) status, which implies some protection but mining, industry and urbanization are allowed. Source: ArcGIS basemap.

vided by the cave's buffer zones, although solely focused on a single karst landform, is by far more efficient.

Caves impose severe obstacles to expanding mining operations or other developments in the Lagoa Santa Karst. Sugai et al. (2015) note that $75.6 \%$ of all registered caves in Brazil are located in areas under mineral consideration or areas with approved mineral permits. While this could suggest a highly vulnerable situation, not a single cave in the Lagoa Santa Karst has had (as of March 2016) its destruction approved by the environmental agency since the promulgation of the 2008 Federal Decree, because agreement on environmental compensation has proved to be difficult and time consuming. Furthermore, even if the compensation is approved, twice as many caves (in the situation of removal of high significance caves) will have to be permanently protected elsewhere, generating a "net" gain in favor of cave preservation.

The highly restrictive nature of cave related law in Brazil, although damaging to economic expansion, has resulted in an increased degree of protection for the environmentally sensitive Lagoa Santa Karst. Despite the fact that other karst landforms, such as dolines, springs, swallets, karren and covered karst are not legally protected, many of these features will either be included in a cave's protection buffer zone or will be inserted in areas bordered by buffer zones. Therefore, new developments in these areas, if possible, will likely involve costly and complex engineering procedures.

Future preservation trends in the Lagoa Santa Karst and other karst areas in Brazil will be strongly influenced by economic and political pressure. Downsizing, downgrading and degazettement of preservation areas are a common problem in Brazil (see review in Bernard et al. 2014) and areas with intrinsic economic value are more prone to such preservation status changes. Cycles of economic development, alternating between high/ low demand for cement and lime, will also push already existing political lobbies to make the law less restrictive, swinging the pendulum between environmentalists and parties favoring economic development. 


\section{CONCLUSIONS}

The Lagoa Santa Karst is, scientifically, the best-known karst area in Brazil and the one with the highest degree of environmental impact. Since Portuguese settlement in the late 1690 s, much of the original vegetation has been removed and the dramatic expansion of urban centers in the late $20^{\text {th }}$ Century resulted in a current population of approximately 500,000 people living in or very close to the karst. Groundwater pollution and overpumping, quarrying, lime particulate deposition and vandalism are among the ongoing threats that have considerably affected existing caves. Although several preservation areas have been established in recent years, they represent a minor portion of the karst and their location does not encompass the most endangered sector of the karst.

The number of registered caves has increased dramatically in recent years due to the level of detail required by environmental studies, particularly the adoption of the legal definition of a cave, i.e., any void enterable by a human being. At present, approximately 2,000 caves have been registered. Many new developments, especially lime and cement quarries, necessitate cave destruction. However, that was made difficult by the 2008 Federal Decree, which imposed highly restrictive criteria for the deter- mination of cave significance. Approximately $95 \%$ of all caves are of either maximum (no impact allowed) or high significance (two high significance caves have to be permanently preserved for each high significance cave removed). In addition to the need to preserve caves, the law dictates that a protection buffer zone (preliminarily of $0.2 \mathrm{~km}^{2}$ ) must also be taken into account.

Although caves are the only karst landform officially protected according to Brazilian law, the superposition of buffer zones results in the protection of vast portions of the karst. Even areas with limited potential for caves, such as covered karst, tend to be included within the amalgamation of buffer zones. The protection warranted by caves and their associated buffer zones is presently a more effective measure than preservation by officially designated protection areas. However, the ever changing and volatile political and economic situation in Brazil creates the potential for downsizing, downgrading and degazettement of preservation areas, as well as future changes in the law, which could move the current preservationist trend towards an economy-focused approach, favoring the exploitation of the karst.

\section{ACKNOWLEDGEMENTS}

This work is the product of long-term experience involving speleological assessment studies for various mining clients in the Lagoa Santa Karst. Preparation of figures was performed by Rafael Igino Cruz. Lorenzza França helped collect and interpret data. Photographs were kindly provided by Luciana Alt. Ana Elisa Brina reviewed the section on deforestation.

\section{REFERENCES}

Araújo, A.G.M., Neves, W.A. \& R. Kipnis, 2012: Lagoa Santa revisited: an overview of the chronology, subsistence, and material culture of paleoindian sites in Eastern Central Brazil.- Latin American Antiquity, 23, 533-550.

Auler, A.S., 1995: Lakes as a speleogenetic agent in the karst of Lagoa Santa, Brazil.- Cave and Karst Science, $21,105-110$.

Auler, A.S., 1999: Karst Evolution and Palaeoclimate in Eastern Brazil.- PhD thesis. University of Bristol, pp. 268.
Auler, A.S., Smart, P.L., Wang, X., Piló, L.B., Edwards, R.L. \& H. Cheng, 2009: Cyclic sedimentation in Brazilian caves: mechanisms and palaeoenvironmental significance.- Geomorphology, 106, 142-153.

Auler, A.S. \& L. B. Piló, 2015a: Caves and mining in Brazil: The dilemma of cave preservation within a mining context.- In: Andreo, B. et al. (eds.) Hydrogeological and Environmental Investigations in Karst Systems. Springer, pp. 487-496, Berlin.

Auler, A.S. \& L.B. Piló, 2015b: Lagoa Santa Karst: Cradle of Brazilian cave studies.- In: Vieira, B. et al. (eds.) 
Landscapes and Landforms of Brazil. Springer, pp. 183-190, Dordrecht.

Bernard, E., Penna, L.A.O. \& E. Araújo, 2014: Downgrading, downsizing, degazettement and reclassification of Protected Areas in Brazil.- Conservation Biology, 28, 939-950.

van Beynen, P. \& K. Townsend, 2005. A disturbance index for karst environments.- Environmental Management, 36, 101-116.

Brasil, 1988: Constituição da República Federativa do Brasil de 1988. Presidência da República.- [Online] Available from: http://www.planalto.gov.br/ ccivil_03/constituicao/constituicao.htm [Accessed $27^{\text {th }}$ February 2016].

Brasil, 2008: Decreto Federal 6.640. Presidência da República.- [Online] Available from: http://www. planalto.gov.br/ccivil_03/_Ato2007-2010/2008/Decreto/D6640.htm [Accessed 27 ${ }^{\text {th }}$ February 2016].

Calò, F. \& M. Parise, 2006: Evaluating the human disturbance to karst environments in Southern Italy.Acta Carsologica, 35, 47-56.

CECAV, 2016: Database of Brazilian caves.- [Online] Available from: http://www.icmbio.gov.br/cecav/ canie.html [Accessed 27 $7^{\text {th }}$ February 2016].

Chen, X., Zhang, Z. \& P. Shi, 2009: The impact of land use and land cover changes on soil moisture and hydraulic conductivity along the karst hillslopes of Southwest China.- Environmental Earth Sciences, $59,811-820$.

CONAMA, 2004: Resolução N. 347.- Diário Oficial, 176, 54-55.

Drew, D. \& H. Hötzl, 1999: Karst Hydrogeology and Human Activities: Impacts, Consequences and Implications.- CRC Press, pp. 338, Rotterdam.

Ford, D.C. \& P.W. Williams, 2007: Karst Hydrogeology and Geomorphology.- Wiley, pp. 576, Chichester.

Galvão, P., Halihan, T. \& R. Hirata, 2015: Evaluating karst geotechnical risk in the urbanized area of Sete Lagoas, Minas Gerais, Brazil.- Hydrogeology Journal, 23, 1499-1513.

Gomes, M.C.A. \& L.B. Piló, 1991: A exploração econômica das cavernas em Minas Gerais nos fins do período colonial.- Espeleo-Tema, 16, 81-91.

Gutierrez, F., Parise, M., De Waele, J. \& H. Jourde, 2014: A review on natural and human-induced geohazards and impacts in karst.- Earth-Science Reviews, $138,61-88$

Harding, K.A. \& D.C. Ford, 1993: Impacts of primary deforestation upon limestone slopes in northern Vancouver Island, British Columbia.- Environmental Geology, 21, 137-143.
Hubbe, A., Haddad-Martim, P.M., Mayer, E.L., Auler, A.S., Piló, L.B. \& W.A. Neves, 2011: Identification and importance of critical depositional gaps in pitfall cave environments: the fossiliferous deposit of Cuvieri Cave, eastern Brazil.- Palaeogeography, Palaeoclimatology, Palaeoecology, 312, 66-78.

IBAMA, 1990: Portaria № 887 de 15 de junho de 1990. Diário Oficial, 117, 11844.

ICMBIO, 2012: Instrução Normativa N. 30.- [Online] Available from: http://www.icmbio.gov.br/cecav/ downloads/legislacao.html [Accessed 27 ${ }^{\text {th }}$ February 2016].

Langer, W.H., 2001: Potential environmental impacts of quarrying stone in karst. A literature review.- United States Geological Survey, Open File Report OF-010484, pp. 34.

Lima Jr., A., 1965: A Capitania de Minas Gerais.- Instituto de História, pp. 231, Belo Horizonte.

Lund, P.W., 1837: Bemærkninger over Vegetationen paa de indre Höisletter af Brasilien, især i plantehistorisk Henseende.- Det kongelige danske Videnskabernes Selskabs naturvidenskabelige og mathematiske Afhandlinger, 6, 145-188.

Lund, P.W., 1840: View of the fauna of Brazil previous to the last geological revolution.- Magazine of Natural History, 4, 1-8, 49-57, 105-112, 153-161, 207-213, 251-259, 307-317, 373-389.

Lund, P.W., 1845: Notice sur des ossements humains fossiles, trouvés dans une caverne du Brésil.- Mémoires de la Societé Royale des Antiquaires du Nord, 49-77.

MMA, 2009: Instrução Normativa N. 2. Ministério do Meio Ambiente.- [Online] Available from: http:// www.icmbio.gov.br/cecav/images/download/ IN\%2002_MMA_criterios_210809.pdf [Accessed $27^{\text {th }}$ February 2016]

Neves, W.A. \& M. Hubbe, 2005: Cranial morphology of early Americans from Lagoa Santa: implications for the settlement of the New World.- Proceedings National Academy of Sciences USA, 102, 18309-18314.

Neves, W.A., Hubbe, M. \& L.B. Piló, 2007: Early Holocene human skeletal remains from Sumidouro Cave, Lagoa Santa, Brazil: History of discoveries, geological and chronological context, and comparative cranial morphology.- Journal of Human Evolution, 52, 16-30.

Neves, W.A. \& L.B. Piló, 2003: Solving Lund's dilemma: new AMS dates confirm that humans and megafauna coexisted at Lagoa Santa.- Current Research in the Pleistocene, 20, 57-60. 
Parise, M. \& V. Pascali, 2003: Surface and subsurface environmental degradation in the karst of Apulia (Southern Italy).- Environmental Geology, 44, 247-256.

Paula Couto, C., 1953: Paleontologia Brasileira. Mamiferos.- Instituto Nacional do Livro, pp. 513, Rio de Janeiro.

Piló, L.B., 1998: Morfologia Cárstica e Materiais Constituintes: Dinâmica e Evolução da Depressão Poligonal Macacos-Baú - Carste de Lagoa Santa, MG.- Doctoral Thesis. Universidade de São Paulo, São Paulo, pp. 267.

Piló, L.B., Auler, A.S., Neves, W.A., Cheng, H. \& R.L. Edwards, 2005: Geochronology, sediment provenance, and fossil emplacement at Sumidouro Cave, a classic late Pleistocene/early Holocene paleoanthropological site in eastern Brazil.- Geoarchaeology, 20, 751-764.

Ravbar, N. \& S. Šebela, 2015: The effectiveness of protection policies and legislative framework with special regard to karst landscapes: Insights from Slovenia.Environmental Science \& Policy, 51, 106-116.
Strauss, A., Oliveira, R.E., Bernardo, D.V., Salazar-García, D.C., Talamo, S., Jaouen, K., Hubbe, M., Black, S., Wilkinson, C., Richards, M.P., Araújo, A.G.M., Kipnis, R. \& W.A. Neves, 2015: The oldest case of decapitation in the New World (Lapa do Santo, East-Central Brazil).- PLoS ONE, 10, e0137456. Doi:10.1371/journal.pone.013745.

Sugai, L.S.M., Ochoa-Quintero, J.M., Costa-Pereira, R. \& F.O. Roque, 2015: Beyond aboveground.- Biodiversity Conservation, 24, 2109-2112.

Tuller, M.P., Ribeiro, J.H. \& A. Danderfer, 1992: Mapeamento Geológico da Área do Projeto VIDA.- CPRM, Belo Horizonte, Unpublished Report.

Vallejos, A., Andreu, J.M., Sola, F. \& A. Pulido-Bosch, 2015: The anthropogenic impact on Mediterranean karst aquifers: cases of some Spanish aquifers.- Environmental Earth Science, 74, 185-198. 